\title{
A Case of Mixoid-type Liposarcoma of the Neck
}

\author{
Atsuyoshi Asahi $^{122)}$, Miki Takahara ${ }^{2)}$ and Yasuaki Harabuchi ${ }^{2)}$
}

Liposarcoma, the second most commom soft-tissue sarcoma in adults, arises predominantly in the extremities or retroperitoneum, less frequently in the head and neck region, and rarely in the neck. We report a case of myxoid-type liposarcoma of the neck.

A 50-year-old man with a few years' history of an enlarging painless swelling in the frontal-medial aspect of the neck, measuring $48 \times 40 \mathrm{~mm}$ in size at the present examination, was found on computed tomography (CT) to have a mass extending between the thyrohyoid muscle and the platysma. We extirpated the tumor with the overlying skin. Histological examination confirmed the diagnosis of myxoid-type liposarcoma. The tumor was completely covered with velamen, and the surgical margin was negative for tumor. No adjuvant therapy has been given, and the patient remains recurrence-free 27 months after surgery.

Keywords : myxoid, liposarcoma, neck

\section{References}

1) Enzinger FM and Weiss SW : Soft Tissue Tumors 3rd Ed. pp 431-466, Mosby, St. Louis, 1995.

2) Newlands SD, Divi V, Stewart CM : mixed Myxoid/round cell liposarcoma of the scalp. Am J Otolaryngol 24: 121-127, 2003.

3) 磯貝理恵子, 川田 暁: 粘液型脂肪肉腫. 皮病診療 26 : 1135-1138, 2004.

4) 大淵豊明, 宇高 毅, 塩盛輝夫, 他：頸部脂肪肉腫の 1 例. 耳鼻・頭頸外科 78: 965-968, 2006.

5) 西村 浩, 長田周治：軟部組織腫瘍. 外科 66:1559-1570, 2004.
6）原聡，伊集院隆宏，志水賢一郎，他：顎下部に発生し た脂肪肉腫の 1 例. 耳鼻・頭頸外科 77: 133-137, 2005.

7) Gritli S, Khamassi K, Lachkhem A, et al. : Head and neck liposarcomas: a 32 years experience. Auris Nasus Larynx 37 : 347-351, 2010.

8) Golledge J, Fisher C and Rhys-Evans PH : Head and neck liposarcoma. Cancer 76: 1051-1058, 1995.

9) 岡野 晋, 清野洋一, 加藤孝邦, 他: 頸部に発生した粘液 型脂肪肉腫の 1 症例. 耳鼻展望 49: 30-34, 2006.

10）佐々木亮, 欠畑誠治, 新川秀一: 顎下部に発生した脂肪肉 腫の 1 例. 耳鼻と臨 54: 76-81, 2008.
1) Department of Otolaryngology, Wakkanai City Hospital

2) Department of Otolaryngology-Head and Neck Surgery, Asahikawa Medical College
Corresponding Author Address : Atsuyoshi Asahi a.asahi@wakkanai-hp.jp 

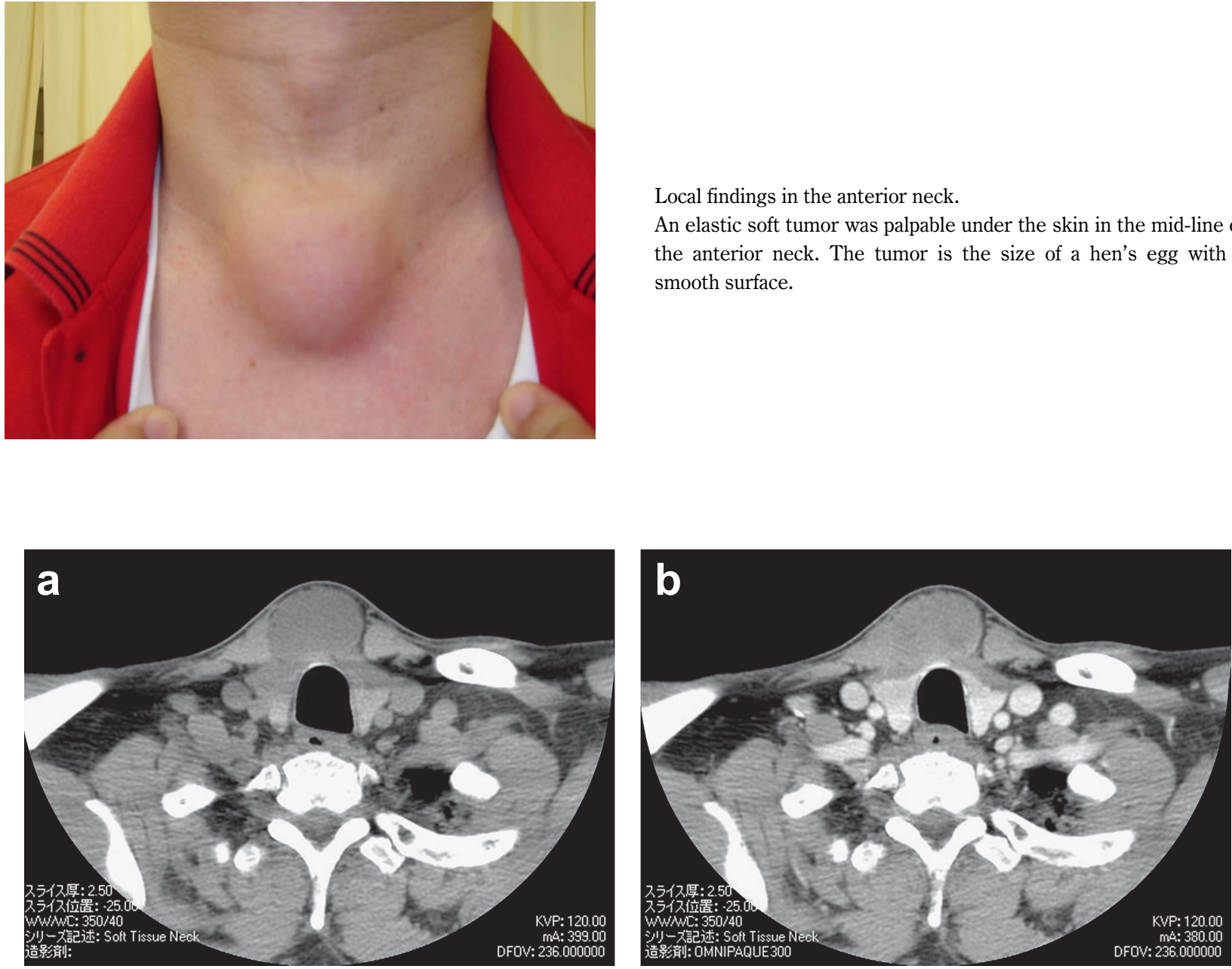

Neck CT scan.

a: Plain CT scan shows a $48 \times 40 \mathrm{~mm}$ mass in the mid-line of the anterior neck between the platysma muscle and the sternohyoid muscle.

b: Enhanced CT scan shows slight enhancement of the margin of the tumor, demonstrating iso-density to surrounding muscles at the center of the tumor.

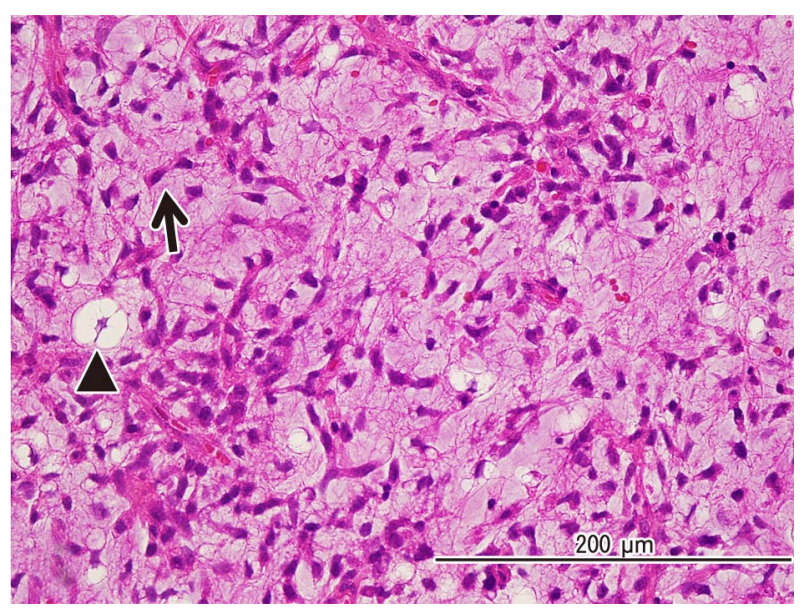

Local findings in the anterior neck.

An elastic soft tumor was palpable under the skin in the mid-line of the anterior neck. The tumor is the size of a hen's egg with a smooth surface.
Pathology of the excised tumor.

HE staining shows signet ring-shaped lipoblasts (arrow head) as well as spindle-shaped lipoblasts, compatible with a diagnosis of myxoid-type liposarcoma. 